NBER WORKING PAPER SERIES

\title{
SUPPRESSING ASSET PRICE INFLATION: THE CONFEDERATE EXPERIENCE, 1861-1865
}

\author{
Richard C.K. Burdekin \\ Marc D. Weidenmier \\ Working Paper 9230 \\ http://www.nber.org/papers/w9230
NATIONAL BUREAU OF ECONOMIC RESEARCH
1050 Massachusetts Avenue
Cambridge, MA 02138
October 2002

The authors thank Bill Brown, Kelly Bedard, Art Denzau, Manfred Keil, Janet Smith, Tom Willett, Karyn Williams and two anonymous referees for helpful comments and discussion and are grateful to Dr. Douglas Ball for assisting us in locating the data on sterling bills of exchange. The views expressed herein are those of the authors and not necessarily those of the National Bureau of Economic Research.

(C) 2002 by Richard C.K. Burdekin and Marc D. Weidenmier. All rights reserved. Short sections of text, not to exceed two paragraphs, may be quoted without explicit permission provided that full credit, including (C) notice, is given to the source. 
Suppressing Asset Price Inflation: The Confederate Experience, 1861-1865

Richard C.K. Burdekin and Marc D. Weidenmier

NBER Working Paper No. 9230

October 2002

JEL No. E52, N21

\section{$\underline{\text { ABSTRACT }}$}

Confederate monetary reforms encouraged holders of Treasury notes to exchange these notes for bonds by imposing deadlines on their convertibility. We show that Confederate funding acts aimed at precipitating the conversion of currency into bonds did temporarily suppress currency depreciation. These acts also triggered upsurges in commodity prices, however, as note holders rushed to spend the currency before their exchange rights were reduced. Asset price stabilization policies seem to have increased the velocity of circulation and counterproductively channeled inflationary pressures into other areas of the economy.

Marc D. Weidenmier Claremont McKenna College and NBER

500 E. Ninth Street

Claremont, CA

91711

marc_weidenmier@mckenna.edu
Richard C. K. Burdekin Claremont McKenna College 500 E. Ninth St.

Claremont, CA

91711

richard_burdekin@mckenna.edu 


\section{Suppressing Asset Price Inflation: The Confederate Experience, 1861-1865}

The absorption of Treasury notes by the funding process is progressing favorably, and will counteract the tendency to a further depreciation of our currency arising from the heavy issues since the $1^{\text {st }}$ of January last.

(Richmond Dispatch, April 15, 1863)

During the Civil War commodity prices rose in the Confederacy while the gold value of Confederate currency and bonds declined. The rate of asset price inflation lagged behind commodity price inflation, however, and there was a greater than 2:1 divergence at the time of two Confederate financial reforms aimed at encouraging exchanges of currency into bonds. These exchanges raised the demand for bonds and boosted bond prices while also supporting the gold value of the currency as the supply of money was reduced. But the period between the announcement and implementation of these reforms saw upward surges in commodity prices with no matching depreciation in the value of the currency against gold. This suggests that the reforms may have channeled inflationary pressures into commodity markets and that an examination of both asset and commodity markets is needed in order to assess the effectiveness of Confederate monetary policy. Just as Bernanke and Gertler (1999) criticize the Bank of Japan for focusing on asset price inflation at the expense of the general price level in the 1989-1997 period so too may Confederate monetary policy have been directed too much towards stabilizing asset markets with less favorable consequences for the prices of other goods and services.

The bursts of commodity price inflation after the reforms were announced suggest that individuals exchanged money for goods as well as for bonds in the run up to the deadline. A real balance effect seems to have operated whereby decreased demand for the old money created excess cash balances that were translated at least in part into an excess demand for goods. Even after the financial reforms reduced the total money supply, the initial surges in commodity price inflation were never fully reversed. There was, in fact, a boost to wealth holdings when the reforms took effect insofar as the stocks of money being retired 
were exchanged for bonds at par -- even though these bonds were then trading at a premium. In this way consumption expenditures may well have been fueled by the gains on the bonds when the exchange occurred. Despite the questions concerning the relative weights that should be attached to bond holdings and money balances as components of private sector net financial assets (see, for example, Patinkin, 1965, pp. 289-290), the changes in the level and market value of bond holdings surely cannot be ignored in the Confederate case. This is especially so given the existence of a ready market for the bonds received with no restrictions on reselling.

From the outset, Confederate currency and bond markets were linked by the fact that note holders enjoyed an imbedded call option on Confederate government bonds. Non-interest-bearing Confederate Treasury notes were issued with the proviso that holders could, at their pleasure, exchange these notes for $8 \%$ government bonds at par. This call option would naturally become increasingly valuable if the bonds rose above par and implied that noteholders would be able to participate fully in any bond market rally even while keeping their funds in the form of highly liquid currency. The $8 \%$ bonds issued under the 1861 $\$ 100$ million loan (authorized by the Act of August 19, 1861 with a minimum denomination of $\$ 100$ ) generally traded at or below par during 1862 , however. And, with no deadline for the exercise of the option, there was no incentive for holders of Confederate Treasury notes to actually convert their money into bonds at that time. In an attempt to induce -- and ultimately force -- early conversion of money into bonds the government instituted three funding acts that limited the time period over which Treasury notes could be exchanged for the higher yielding $8 \%$ bonds. After the deadline, these notes could only be exchanged for lower yielding bonds -- or in some cases would no longer be convertible at all.

As the funding acts were imposed, Confederate bonds finally rose above par. And significant volumes of Treasury notes were exchanged for bonds prior to the deadlines imposed by the respective acts. At least by the beginning of 1863, Confederate Secretary Memminger (1863a, pp. 442-45) was clearly concerned that the initial voluntary exchanges of money for bonds would be insufficient to curb 
inflationary pressures, however, and urged much more draconian steps -- some of which were eventually adopted under the March 23, 1863 Act:

Prices will reach the height adjusted by the scale of issues, and they can only be restored to their usual condition by a return to the normal standard of currency. In other words, the only remedy for an inflated currency is a reduction of the circulating medium ... I would respectfully propose that ... the issues of treasury notes bearing date prior to the $1^{\text {st }}$ December, 1862 shall cease to be currency ... Hitherto the policy of the government has sought to absorb the circulation by inducements alone ... It is proposed now to supply the deficiency by a small portion of constraint. We see on every side of us indications of the abundance of money ...

In this paper we assess the overall consequences of the Confederate funding acts for asset prices and commodity prices. We combine newly-collected weekly data on Confederate bond prices with a weekly series on the gold value of Confederate currency also collected from primary newspaper sources (see Burdekin and Weidenmier, 2001, and Weidenmier, 2002). ${ }^{1}$ We compare our data on currency depreciation with available monthly data on commodity prices in Richmond (Berry, 1985) and the eastern Confederacy (Lerner, 1955). We show that significant reductions in the rate of currency depreciation followed the implementation of two of the three reforms but also illustrate the surge in commodity prices that occurs between the announcement and implementation dates. An acceleration in commodity prices relative to the gold price of Confederate currency is evident not only for the later February 17, 1864 Act - that essentially repudiated nearly one-third of the Confederate money stock -- but also for the earlier October 1862 Act that merely imposed a deadline for exchanging Treasury notes into higher yielding bonds. Econometric analysis of the weekly data confirms that there was a significant increase in gold values when the reforms were implemented. Only the March 1863 Act did not match this pattern. This exception may be partly due to the much smaller quantity of notes actually exchanged for bonds as well as the fact that the effective date of August 1, 1863 occurred in the aftermath of the Battle of Gettysburg fought in July 1863. 


\section{The Evolution of Confederate Interest Rate Policy}

The first funding act was passed on October 13, 1862. Notes issued prior to December 1, 1862 could only be exchanged for $8 \%$ bonds until a deadline eventually set at April 22, 1863 . Thereafter these notes, together with all subsequent notes issued after December 1, 1862, would be exchangeable only for $7 \%$ bonds. ${ }^{2}$ The effects of this Act on the demand for money appeared to be well-anticipated by Confederate Treasury Secretary Memminger in his letter of October 6, 1862 to President Davis:

If after a certain date no 8 per cent bonds be issued, except to fulfill existing contracts, it is obvious that the currency now in circulation would have an advantage over that afterwards issued, and the effect would be a general effort on the part of moneyed men to get possession of ... those notes that were fundable in bonds at the higher rate of interest. ${ }^{3}$

As the $8 \%$ funding deadline approached, the older notes still convertible into $8 \%$ bonds prior to April 22 did indeed rise to a premium against the newer notes that were exchangeable only into 7\% bonds. The Richmond Dispatch (April 15, 1863) states that these older notes were "in demand" and trading at a more than $2 \%$ premium. The day before the deadline the old notes were still being offered at a $1 \%$ premium to the new notes but, with their exchangeability into $8 \%$ bonds about to end, "most of the brokers declined to buy" (Richmond Dispatch, April 22, 1863). This implies not only that holders attached significant value to the right to exchange notes for $8 \%$ bonds rather than $7 \%$ bonds but also that the right to exchange Treasury notes for bonds at par was still viewed as a valuable option in the spring of 1863.

After the act took effect, the impact on commodity prices was noted by the Richmond Dispatch (April 16, 1863): 
During the past few days, a downward tendency in the prices of nearly all articles of merchandise has been developed-the chief cause of which, as heretofore stated, is the reduction of the amount of currency by the rapid funding of Treasury notes.

The gold value of the currency also rose in late April 1863. The Richmond Dispatch (April 29, 1863) noted that the "rate of premium for specie has undergone a decided decline since our last report." At the same time, the value of the $8 \%$ bonds in terms of Confederate currency rose substantially and during the second half of April 1863 these bonds climbed to a 10\% premium (see Data Appendix). The period between the announcement of the funding act in October 1862 and its implementation in April 1863 was marked by a burst of commodity price inflation, however. The growth of commodity prices -- as measured both by the Lerner and Berry price indices -- over and above our currency price index for the price of a gold dollar in terms of Confederate Treasury notes can be seen in Figure 1. The Lerner and Berry indices each more than doubled between October 1862 and April 1863. The ratios of these two commodity price indices to the currency index also rose sharply after November 1862, and there is a greater than 2:1 differential during April 1863 - see Figure 2 and the Data Appendix. Both ratios later briefly went back to just above 1:1 in August 1863 prior to embarking on a renewed upward trends. ${ }^{4}$ The disparate reactions of currency and commodity prices to the first funding act suggests that inflationary pressures were heavily channeled into commodity prices and offers support for Lerner's (1954, p. 516) argument that the Confederate funding acts boosted the velocity of circulation as note holders sought to unload their notes before their exchange rights were reduced under the terms of the funding acts. As noted earlier, this is also consistent with the direct link between money and spending implied by the real balance effect. 
In the face of rapid issuance of new notes needed to fund the Confederacy's military

efforts in 1863, a second funding act was passed even before the first act had taken effect. Under the Funding Act of March 23, 1863 the right to exchange Treasury notes for even 7\% bonds was to end on August 1, 1863. After that date, notes issued prior to December 1, 1862 would not be fundable in bonds at all while notes issued after December 1, 1862 would be fundable only in 4\% 30 -year bonds. The imposition of this new funding deadline again reportedly had a significant impact on Confederate money markets. The Richmond Dispatch (August 4, 1863) states:

As the time within which the old issues of Treasury notes were fundable has expired, they have been refused since $1^{\text {st }}$ August by a number of persons who continued to receive them up to that date. Fortunately there are not many afloat here, and persons holding them need not fear any loss, as the Confederate tax collectors will soon afford the means for retiring them from circulation. Let everybody pay taxes in the old notes, and get them out of the way.

Todd (1954, p. 72) estimates, however, that the second funding act withdrew only $\$ 21$

million in Treasury notes from circulation in exchange for bonds. ${ }^{5}$ The total for the first act was much higher with Todd (1954, p. 67) stating that more than $\$ 163$ million in notes were withdrawn form circulation. ${ }^{6}$ Godfrey $(1978$, p. 120) summarizes the overall impact of the first two acts as follows:

Prior to the funding, nearly every dollar of currency issued by the Confederate government added a dollar to currency in circulation and thereby, to the money stock. However, funding reduced the volume of Confederate currency in circulation. Between mid-February 1862 and January 1863, the Confederate Treasury issued $\$ 389$ million in currency, and the volume in circulation rose slightly over 90 percent of this amount. This contrasts with the following nine months when Treasury notes issued rose $\$ 415$ million, but notes in circulation were up only $\$ 245$ million. Notes in circulation increased only about 60 percent of the notes issued. . . Of course, the volume of Treasury notes removed from circulation by funding accounts for the difference. . . The Confederate Treasury issued more notes in the latter period but increased the money supply less because a significant amount of the notes were converted into long-term bonds. 
Notwithstanding the effects of the funding acts, the overall supply of non-interest-bearing notes in circulation still expanded from $\$ 289$ million at the beginning of 1863 to more than $\$ 720$ million by January 1,1864 . The premium on the $8 \%$ bonds in terms of Confederate currency rose mildly to around $15 \%$ at the end of 1863 . But the gold premium began to soar in late 1863 , reaching 20:1 in Richmond on January 2, 1864 (Burdekin and Weidenmier, 2001). As a last resort, the Confederate government passed the February 17, 1864 Act that mandated that most Confederate Treasury notes then outstanding be exchanged for 4\% bonds by April 1, 1864 or else face a 33 1/3 \% "tax." (The deadline was extended to July 1, 1864 west of the Mississippi.) The premium on the $8 \%$ bonds east of the Mississippi was driven up to $25 \%$ after this Act was passed and the gold value of Treasury notes also rose. In contrast to previous measures whereby the funding of notes for bonds had quickly been more than offset by issues of new notes, the 1864 Act produced an overnight near-one-third shrinkage in the Confederate money supply east of the Mississippi in April 1864.

As with the first act, however, there was a surge in commodity prices in the period between the announcement of this new act in February 1864 and its implementation in April 1864. Indeed, even though the gold price of Confederate currency increased by only $2 \%$ over this period, Lerner's index increased by over $51 \%$ and Berry's index increased by over $43 \%$. For Lerner's index, the ratio of commodity prices to currency prices increased from 1.31 in February 1864 to 1.94 in April 1864 before peaking at 2.54 in May. In terms of Berry’s index, the ratio accelerated from 1.61 in February to 2.26 in April before, again, peaking in May. Although each of the commodity and currency indices then fell until at least August 1864 - with the decline 
continuing until October 1864 in the case of Lerner's index - only the currency index ever dropped below its February 1864 level. As far as commodity prices are concerned, it appears that the subsequent deflationary effects of the reduced money stock never entirely offset the initial inflationary effects of increased velocity of circulation. And the Confederacy's success in effectively supporting the gold value of Confederate assets came at the expense of initially channeling strong inflationary pressures into the commodity markets.

The gold premium itself remained below the February 1864 level until September 1864 and did not rise significantly until November 1864, by which time expanding new issues of Confederate Treasury notes reversed the temporary decline in the money supply effected by the February 1864 Act. Memminger's replacement as Treasury Secretary, Trenholm (1864, p. 6) accurately summarized the bleak situation near the end of the war: "Unless a uniform and stable value can be given to the treasury notes, the effort to carry on the war through their instrumentality, must of necessity be abandoned." Thereafter even direct government intervention in the gold market in early 1865 could not arrest the accelerating rate of currency depreciation that continued until Confederate currency was rendered essentially worthless with the surrenders of General Lee and General Johnston in April 1865.

\section{Quantifying the Effects of the Funding Acts on Confederate Asset Prices}

We identify a consistent relationship between the gold price of Confederate currency and the gold price of Confederate bonds. ${ }^{7}$ Using new weekly data on bond prices collected from contemporary Richmond, Wilmington and Mobile newspapers we first show in Figure 3 the rising trend of the gold yields on Confederate bonds. As with Davis and Pequet (1990) - whose 
analysis focused only on monthly bond data - these are yields to maturity calculated based on an 1881 end-date. ${ }^{8}$ Figure 4 plots the gold price of the $1861 \$ 100$ million dollar loan and the gold price of Confederate currency between January 1862 and January $1865 .{ }^{9}$ The two series appear to move together both in the pre-May 1864 period and also over the remaining July 1864-January 1865 period for which data on both series exist. Empirical testing can only be employed over the January 1862-April 1864 portion of the sample, however, owing to the lack of bond price quotes during May and June 1864. In the face of the vast bond issues required once the February 17, 1864 took effect in the eastern Confederacy on April 1, 1864, regular bond quotes temporarily disappear in the Richmond newspapers (and those of other major Southern cities) until July 1864.

Consistent with the near-perfect correlation evident in Figure 4, Johansen maximum likelihood tests show the gold price of the bonds and the gold price of Confederate currency to be cointegrated between January 1862 and March 1864 (see Table 1). The existence of a one-to-one relationship between bond prices and currency prices can be rejected at better than the $99 \%$ confidence level, however. ${ }^{10}$ Thus, at least up until March 1864, holders apparently did not view money and bonds as perfect substitutes - implying also that they were not yet convinced that all the bonds would be monetized eventually. Based on the long-run equilibrium relationship uncovered by the cointegration testing, we then estimate error-correction equations for the change in the gold value of the bonds and the change in the gold price of Confederate currency. Lagged values of the changes in these two variables are entered on the right-hand-side of each equation together with a constant and the error-correction term. We initially add a dummy variable for each of the three funding acts, a war dummy for Northen victories (defined as +1 for 
a major Union victory and zero otherwise) and a war dummy for Southern victories (defined as +1 for a major Confederate victory and zero otherwise). ${ }^{11}$ A list of the battles is provided in Table 2 (see also Weidenmier, 2002). The dummies for the funding acts are set equal to +1 for the week leading up to the funding deadline that was imposed and zero otherwise. ${ }^{12}$ The expected sign on the Northern dummy is negative but the expected sign on each other dummy variable is positive as the funding acts and favorable war news should all raise the gold value of Confederate financial instruments, ceteris paribus. We also re-ran the regression with each of the battles entered individually so as to avoid imposing the restriction that each Northern or Southern victory had an equal-sized effect.

Table 3 sets out the reaction of money and bond price changes to the deviations from long-run equilibrium represented by the error-correction term, the reform dummies and the grouped Northern and Southern victories (labeled "North" and "South", respectively). Although the money price response is insignificant, the bond price response is significant at the $5 \%$ level. The relatively large coefficient of -0.755 on the error-correction term implies rapid bond market adjustment back towards the long-run equilibrium -- with just over three-quarters of the adjustment completed within one week. Money and bond prices also respond significantly to the funding acts and to war news. There is a large shift in gold values at the time of the first funding act that took effect in April 1863. The results suggest that there was an approximate 12\% boost to the gold value of Confederate $8 \%$ bonds at that time and a $9.5 \%$ boost to the gold value of Confederate Treasury notes. These coefficients are similar in size to those associated with the Northern war dummy, which like the first reform dummy is significant at the $5 \%$ level or better in both the bond equation and the currency equation. The insignificance of the Southern war 
dummy, meanwhile, implies that (contrary to McCandless, 1996) the effects of war news were asymmetric - perhaps because, in the absence of a decisive victory on Northern soil, the given Confederate victories were not seen as hastening a favorable end to the conflict. The 1864 Currency Reform also has the expected positive sign but is significant only at the $10 \%$ level in the bond and money equations. The indicated effects remain surprisingly strong, however, given that the 1864 reform takes effect only in the last month of the sample period, making any such shift hard to detect econometrically. ${ }^{13}$

Re-running the regression with the 12 battles entered individually generally has little effect on either the size or significance of the coefficients associated with the reform dummies. The third reform dummy does now, however, fall just below the $10 \%$ significance level in the money equation. The implied adjustment speed decreases slightly as the coefficient on the errorcorrection term declines from -0.755 to -0.666 . But this still implies that approximately twothirds of the adjustment takes place within the first week. The results for the battle dummies themselves confirm the earlier inference that there is no positive impact of Confederate victories. None of the dummies for the Seven Days Battles around Richmond, Second Manassas, Fredericksburg, Chancellorsville or Chickamauga is significant at even the $10 \%$ level. ${ }^{14}$ Meanwhile, among the Northern victories, Gettysburg/Vicksburg and Sharpsburg (Antietam) produce large negative effects that are in each case significant at the $1 \%$ level. The strong effects apparently associated with these two battles are consistent with them typically being considered to form major turning points in the Civil War (see also Weidenmier, 2002). 
We have not so far discussed the dummy for the second reform act, which took effect on August 1, 1863, however. This dummy is itself significant either at the $10 \%$ level -- or, in one case, at the 5\% level -- in the bond and money equations in Tables 3 and 4, but has the wrong (negative) sign. We believe that the explanation for the seemingly-perverse effects accompanying the implementation of the second funding act lies not only in the relatively small number of notes actually exchanged for bonds but also in its coming on the heels of news of Confederate defeat at the Battle of Gettysburg in July 1863. Although our war dummies capture the immediate impact of news of this defeat, more persistent negative effects on Confederate financial instruments held abroad are demonstrated by Brown and Burdekin (2000) and Weidenmier (2000). Whereas Confederate cotton bonds traded in London and Confederate bonds traded in Amsterdam begin a months' long plunge of over 30\% after Gettysburg, the gold values of domestic Confederate bonds and Confederate currency actually remain quite stable between August and November 1863. The Confederate bonds held abroad were not subject in any way to the provisions of the funding acts. Therefore their extended decline in value in the latter half of 1863 may offer a rough counterfactual of what would have happened to the gold value of domestically-held Confederate currency and bonds in the absence of the funding acts. In other words, the second funding act may still have at least blunted the depreciation in the gold value of domestically-held Confederate financial instruments that followed the Battle of Gettysburg.

Support for this view arises from the price movements for sterling bills of exchange during 1863. These bills represented exchanges of Confederate currency for the future delivery of pounds sterling - usually 60 days after the bill was drawn up. The premium for sterling in 
terms of Confederate currency rose with the expected rate of Confederate currency depreciation. Table 5 reports all available quotes for 60-day sterling drafts that could be located in the National Archives. A continued uptrend in the sterling premium is evident in the data for 1861 and 1862. After reaching 200 on December 30, 1862 the premium increases only slightly to 230 on April 6, 1863. But the next quotation from July 22, 1863 shows a near doubling of the premium. This greatly increased premium occurs in the aftermath of the Battle of Gettysburg and appears to be consistent with the quite devastating declines evident in Confederate bonds that were traded abroad. We can only conclude that the estimated coefficient on the dummy for the second funding act conflates positive effects of the second funding act on domestically-held bonds with the continued negative effects of the Gettysburg defeat evident in other Confederate financial instruments.

\section{Conclusions}

By imposing deadlines on convertibility into higher yielding bonds the government was able to induce substantial exchanges of money for bonds. We present evidence that at least two out of the three Confederate funding acts were effective in temporarily suppressing the rate of currency depreciation. These acts also triggered upsurges in commodity prices, however, as note holders rushed to spend the currency before their exchange rights were reduced. The widening gap between commodity and asset prices following the passage of the first and third acts is consistent with the rising velocity of circulation noted by Lerner (1954). Confederate asset price stabilization policies seem, therefore, to have initially channeled inflationary pressures into other areas of the economy -- with decreased money demand being translated, at least in part, into an 
excess demand for goods. The declining prices after the acts took effect must therefore be set against the preceding sharp run-up in prices after the monetary reforms were announced. 


\section{Footnotes}

1. Past research has been hampered by the lack of a reliable series on the gold value of Confederate currency with, for example, McCandless (1996) relying upon a newspaper column of unknown origin that differs significantly from actual trades reported in contemporary Richmond papers.

2. As Congress had neglected to provide the Secretary of the Treasury with the authority to issue the bonds called for under the October 13, 1862 Act, the first Act had to be supplemented with a further Act of February 20, 1863 so as to allow the new bonds to be issued (Todd (1954, p. 66).

3. Quoted in Todd (1954, p. 66). Memminger (1863a), in his Treasury Report of January 10,1863 , also pointed out that rapid depreciation of the notes in which the interest on the bonds was paid had been reducing the incentive to convert by lowering the real return: "Bonds at a high rate of interest have been offered; but the inducement has been abated by the depreciation of the currency in which the interest is paid" (see Capers, 1893, p. 445).

4. This closing of the gap may well reflect arbitrage between the relatively cheaper gold and the relatively more expensive commodities. At the very least, there is more to this picture than the effects of progressive supply shortages that, while potentially helping to account for a widening of the gap, could scarcely explain its subsequent closure.

5. The new notes issued in 1863 were to be fundable in $6 \%$ bonds for the first year and thereafter would be fundable only in $4 \%$ bonds. 
6. Although Memminger (1863b, p. 458) reported that only $\$ 65$ million in Treasury notes were funded and cancelled between January 1, 1863 and September 30, 1863, Todd's figures are based on Thian's (1878) exhaustive analysis of the primary Treasury records.

7. We do not attempt econometric analysis with the commodity price indices as the monthly data yields too limited a number of observations.

8. Davis and Pecquet (1990) stress the importance of substitution between call certificates and bonds and point to the existence of an approximate $2 \%$ premium on the bonds over much of the 1862-1864 period. The role played by call certificates changed substantially when their free exchangeability for Treasury notes ended under the March 23, 1863 Act, however. As Todd (1954, pp. 70-71) points out: “All call certificates of every description, outstanding after July 1,1863 , were to be considered bonds ... [and] every certificate not reconverted within six months ... was to be exchanged for $6 \% 30$-year bonds."

9. Although we have seen no references to these bonds actually circulating, they were nevertheless viewed as liquid financial instruments with active secondary markets (Davis and Pecquet, 1990).

10. This finding holds even if we include the reform dummies in the cointegrating space in addition to their existing role as short-run shift factors.

11. The rationale for adding these war dummies is that negative war news could signal greater expected future money growth and/or a higher probability that the bond issues would have to be entirely monetized in the future. 
12. The reform dummies are not defined for the earlier post-announcement period because there are no economic rationale for option holders to exercise the option prior to the expiry date (Copeland and Weston, 1988, pp. 253-255).

13. The potency of the 1864 Act is, however, convincingly demonstrated by the contrasting experience of the eastern Confederacy vs. that of the Trans-Mississippi. The Act took effect three months later in the Trans-Mississippi and the temporary reversal of the depreciation of Confederate currency was also similarly delayed (see Burdekin and Weidenmier, 2001).

14. In the case of Chancellorsville the dummy also likely captures word of General “Stonewall” Jackson's death on May 11, 1863 from wounds received by friendly fire on the evening of May 2 -- thus conflating negative news with the favorable outcome of the battle itself. 


\section{References}

Bernanke, Ben, and Mark Gertler. "Monetary Policy and Asset Price Variability.” In New Challenges for Monetary Policy, a Symposium Sponsored by the Federal Reserve Bank of Kansas City, Kansas City, Mo., 1999, pp. 77-128.

Berry, Thomas Senior. Richmond Commodity Prices: 1861-1865, Bostwick Paper No. 5, The Bostwick Press, University of Richmond, Va., 1985.

Brown, William O., Jr., and Richard C. K. Burdekin. "Turning Points in the U.S. Civil War: A British Perspective.” Journal of Economic History 60, no. 1 (March 2000): 216-31.

Burdekin, Richard C. K., and Marc D. Weidenmier. "Inflation is Always and Everywhere a Monetary Phenomenon: Richmond vs. Houston in 1864." American Economic Review 91, no. 5 (December 2001): 1621-30.

Capers, Henry D. The Life and Times of C. G. Memminger. Richmond, Va.: Everett Waddey, 1893.

Copeland, Thomas E., and J. Fred Weston. Financial Theory and Corporate Policy, Third Edition. Reading, Mass.: Addison-Wesley, 1988.

Davis, George K., and Gary M. Pecquet. "Interest Rates in the Civil War South.” Journal of Economic History 50, no. 1 (March 1990): 133-48.

Godfrey, John Munro. Monetary Expansion in the Confederacy. New York: Arno Press, 1978.

Lerner, Eugene M. “The Monetary and Fiscal Programs of the Confederate Government, 186165.” Journal of Political Economy 62, no. 6 (December 1954): 506-22.

Lerner, Eugene M. "Money, Prices, and Wages in the Confederacy, 1861-65.” Journal of Political Economy 63, no. 1 (February 1955): 20-40. 
McCandless, George T., Jr. "Money, Expectations, and the U.S. Civil War.” American Economic Review 86, no. 3 (June 1996): 661-71.

Memminger, C. G. Report of the Secretary of the Treasury, Richmond, Va., January 10, 1863 (reprinted in Capers, 1893, pp. 438-456). (1863a)

Memminger, C. G. Report of the Secretary of the Treasury, Richmond, Va., December 7, 1863 (reprinted in Capers, 1893, pp. 457-476). (1863b)

Osterwald-Lenum, Michael. “A Note with Quantiles of the Asymptotic Distribution of the Maximum Likelihood Cointegration Rank Test Statistics.” Oxford Bulletin of Economics and Statistics 54, no. 3 (August 1992): 461-72.

Patinkin, Don. Money, Interest, and Prices: An Integration of Monetary and Value Theory, Second Edition. New York: Harper \& Row, 1965.

Record of Civil and Miscellaneous Warrants of the Fiscal Year 1861-1862, Record Group 109, Chapter 10, Volume 221, National Archives, Washington, DC.

Record of Civil Warrants January 1, 1863-December 31, 1863, Record Group 109, Chapter 10, Volume 257, National Archives, Washington, DC.

Thian, Raphael P. Reports of the Secretary of the Treasury of the Confederate States of America 1861-1865. Washington, DC: Privately published, 1878 (microfilm copy located in the National Archives)

Todd, Richard Cecil. Confederate Finance. Athens, Ga.: University of Georgia Press, 1954.

Trenholm, G. A.. Report of the Secretary of the Treasury, Richmond, Va., November 7, 1864. Weidenmier, Marc D. “The Market for Confederate Cotton Bonds.” Explorations in Economic History 37, no. 1 (January 2000): 76-97. 
Weidenmier, Marc D. "Turning Points in the U.S. Civil War: Views from the Grayback Market." Southern Economic Journal 68, no. 4 (April 2002): 875-90. 


\section{Table 1}

\section{Johansen Maximum Likelihood Tests for Cointegration}

\begin{tabular}{|c|c|c|c|}
\hline Null & Alternative & Test & $95 \%$ \\
\hline Hypothesis & Hypothesis & Statistic & Critical Value \\
\hline$\lambda_{\text {TRACE }}$ tests & & $\lambda_{\text {TRACE }} \mathrm{V}$ & \\
\hline $\mathrm{r}=0$ & $r>0$ & 20.13 & 15.197 \\
\hline$\lambda_{\text {MAX }}$ tests & & $\lambda_{\text {MAX }} \mathrm{va}$ & \\
\hline $\mathrm{r}=0$ & $\mathrm{r}=1$ & 19.70 & 14.036 \\
\hline \multicolumn{4}{|c|}{ lag length of VAR $=4$} \\
\hline \multicolumn{4}{|c|}{ Long-Run Equilibrium Relationship } \\
\hline
\end{tabular}

Test of the Restriction of a One-to-One Linkage between Money and Bonds

Chisqr(1) $=20.92$

$\mathrm{p}$-value $=.000$

Note: Critical Values for the Johansen cointegration tests are obtained from OsterwaldLenum, 1992. 


\section{Table 2}

Some Major Military Events of the US Civil War January 1862 - April 1864

\section{Date}

April 6-7, 1862

Late April 1862

Late June - Early July, 1862

August 30, 1862

September 17-19, 1862

December 11-15, 1862

December 31 - Jan. 2, 1863

May 2, 1863

July 1-3, 1863

July 4, 1863

September 19-20, 1863

November 25, 1863

\section{Battle}

Pittsburgh Landing (Shiloh)

Fall of New Orleans

Seven Days

Second Manassas (Bull Run)

Sharpsburg (Antietam)

Fredericksburg

Murfreesboro (Stones River)

Chancellorsville

Gettysburg

Vicksburg

Chickamauga

Chattanooga
Victor

North

North

South

South

North

South

North

South

North

North

South

North 
Table 3

Basic Cointegration Model Results

Variable

Constant

Speed of

Adjustment

Reform1

Reform2

Reform3

North

South

$\Delta$ Bond $_{\mathrm{t}-1}$

$\Delta$ Bond $_{\mathrm{t}-2}$

$\Delta$ Bond $_{\mathrm{t}-3}$

$\Delta$ Money $_{\mathrm{t}-1}$

$\Delta$ Money $_{\mathrm{t}-2}$

$\Delta$ Money $_{\mathrm{t}-3}$
Bond Equation

0.187

$(2.071)^{* *}$

$-0.755$

$(-2.364) * *$

0.118

$(2.358)^{* *}$

$-0.091$

$(-1.919)^{*}$

0.068

$(1.825)^{*}$

$-0.092$

$(-3.279)^{* * *}$

0.018

(0.545)

$-0.392$

$(-1.004)$

$-0.959$

$(-2.348)^{* *}$

$-0.172$

$(-0.477)$

0.173

(0.441)

0.897

$(2.199) * *$

0.185

(0.511)
Money Equation

0.066

(0.732)

$-0.337$

(-1.052)

0.095

$(2.039) * *$

$-0.095$

$(-1.992)^{* *}$

0.062

$(1.658)^{*}$

$-0.095$

$(3.291)^{* * *}$

0.018

(0.548)

$-0.232$

$(-0.591)$

0.897

$(-2.548) * *$

$-0.082$

$(-0.225)$

$-0.006$

$(-0.016)$

0.913

$(2.228)^{* *}$

0.064

$(0.176)$

where t-statistics are in parentheses, and

$*, * *$, and $* * *$ denote significance at the $10 \%, 5 \%$ and $1 \%$ levels, respectively 
Table 4

Cointegration Model with Separate Dummies for Each Major Battle

\begin{tabular}{|c|c|c|}
\hline Variable & Bond Equation & Money Equation \\
\hline Constant & $\begin{array}{l}0.161 \\
(1.828)^{*}\end{array}$ & $\begin{array}{c}0.034 \\
(0.383)\end{array}$ \\
\hline $\begin{array}{l}\text { Speed of } \\
\text { Adjustment }\end{array}$ & $\begin{array}{l}-0.666 \\
(-2.130) * *\end{array}$ & $\begin{array}{l}-0.227 \\
(-0.718)\end{array}$ \\
\hline Reform1 & $\begin{array}{l}0.109 \\
(2.497)^{* *}\end{array}$ & $\begin{array}{c}0.088 \\
(1.986)^{* *}\end{array}$ \\
\hline Reform2 & $\begin{array}{l}-0.077 \\
(-1.720)^{*}\end{array}$ & $\begin{array}{l}-0.082 \\
(-1.812)^{*}\end{array}$ \\
\hline Reform3 & $\begin{array}{l}0.062 \\
(1.763)^{*}\end{array}$ & $\begin{array}{c}0.057 \\
(1.591)\end{array}$ \\
\hline Pittsburgh Landing (Shiloh) & $\begin{array}{c}0.015 \\
(0.264)\end{array}$ & $\begin{array}{c}0.008 \\
(0.138)\end{array}$ \\
\hline Fall of New Orleans & $\begin{array}{l}-0.083 \\
(-1.187)\end{array}$ & $\begin{array}{l}-0.081 \\
(-1.144)\end{array}$ \\
\hline Seven Days & $\begin{array}{c}0.058 \\
(0.742)\end{array}$ & $\begin{array}{c}0.061 \\
(0.770)\end{array}$ \\
\hline Second Manassas (Bull Run) & $\begin{array}{c}0.006 \\
(0.090)\end{array}$ & $\begin{array}{l}-0.004 \\
(-0.061)\end{array}$ \\
\hline Sharpsburg (Antietam) & $\begin{array}{l}-0.185 \\
(-3.232) * * *\end{array}$ & $\begin{array}{l}-0.181 \\
(-3.129) * * *\end{array}$ \\
\hline Fredericksburg & $\begin{array}{c}0.028 \\
(0.393)\end{array}$ & $\begin{array}{c}0.038 \\
(0.535)\end{array}$ \\
\hline Murfreesboro (Stones River) & $\begin{array}{c}0.080 \\
(1.140)\end{array}$ & $\begin{array}{c}0.090 \\
(1.271)\end{array}$ \\
\hline Chancellorsville & $\begin{array}{c}0.001 \\
(0.029)\end{array}$ & $\begin{array}{l}-0.004 \\
(-0.067)\end{array}$ \\
\hline
\end{tabular}




$\begin{array}{llc}\text { Gettysburg/Vicksburg } & -0.168 & -0.152 \\ & (-3.212)^{* * *} & (-2.869)^{* * *} \\ \text { Chickamauga } & 0.110 & 0.113 \\ & (1.568) & (1.583) \\ \text { Chattanooga } & -0.032 & -0.040 \\ & (-0.445) & (-0.552) \\ \Delta \text { Bond }_{\mathrm{t}-1} & -0.409 & -0.269 \\ & (-1.091) & (-0.711) \\ \Delta \text { Bond }_{\mathrm{t}-2} & -0.714 & -0.846 \\ & (-1.733)^{*} & (-2.029)^{* *} \\ \Delta \text { Bond }_{\mathrm{t}-3} & -0.132 & -0.057 \\ & (-0.386) & (-0.165) \\ \Delta \text { Money }_{\mathrm{t}-1} & & 0.020 \\ & 0.181 & (0.052) \\ \Delta \text { Moneyt-2 } & (0.483) & 0.743 \\ & & (1.805)^{*} \\ & 0.690 & 0.039 \\ & (1.694)^{*} & (0.113) \\ & 0.148 & \end{array}$

All models were tested for serial correlation at various lag lengths using Box-Ljung and LM tests. The null hypothesis of no autocorrelation could not be rejected. (Also see notes to Table 3.) 


\section{Table 5}

\section{Premium on Sterling Bills of Exchange May 1861 - July 1863}

\begin{tabular}{|c|c|c|c|}
\hline 1861 & Premium & 1863 & Premium \\
\hline April 18 & 9 & January 5 & 195 \\
\hline May 2 & par & January 6 & 200 \\
\hline May 11 & par & April 6 & 230 \\
\hline August 11 & $8.75-12.5$ & July 22 & 385 \\
\hline September 23 & $10-13.5$ & & \\
\hline October 1 & 11 & & \\
\hline October 19 & 13.5 & & \\
\hline October 21 & 11 & & \\
\hline November 29 & 25 & & \\
\hline \multicolumn{4}{|l|}{1862} \\
\hline January 3 & 25 & & \\
\hline January 20 & 25 & & \\
\hline March 7 & 75 & & \\
\hline April 19 & 70 & & \\
\hline April 24 & $75-85$ & & \\
\hline April 25 & 70 & & \\
\hline April 26 & 80 & & \\
\hline May 5 & 80 & & \\
\hline May 7 & $100-101$ & & \\
\hline May 31 & 85 & & \\
\hline December 30 & 200 & & \\
\hline
\end{tabular}

Sources: Thian (1878, pp. 83-84); Record of Civil and Miscellaneous Warrants of the Confederate Government of the Fiscal Year 1862-1863; Record of Civil Warrants January 1, 1863 - December 31, 1863. 
Figure 1

Confederate Commodity and Currency Price Indices, 1861 -1865

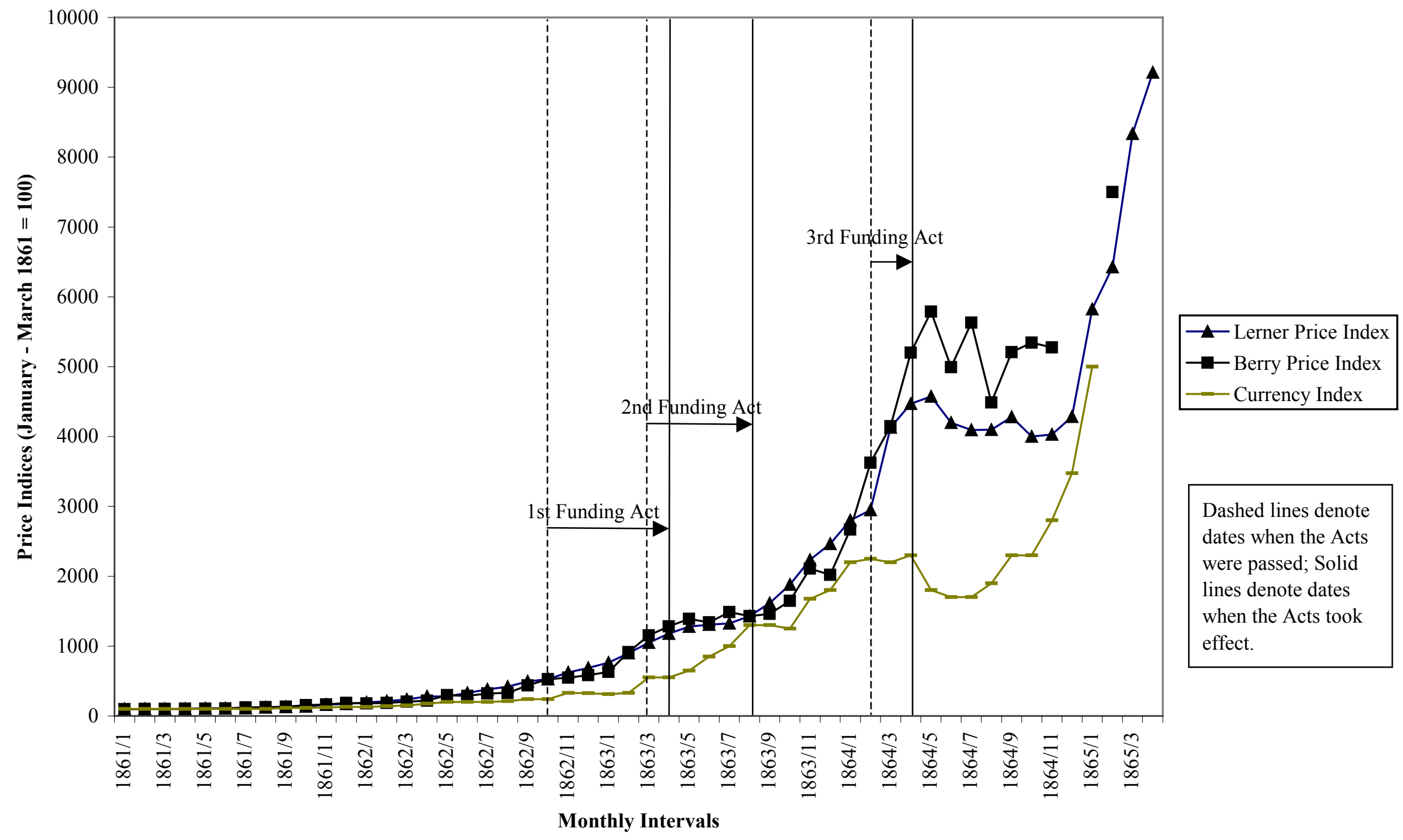


Figure 2

Ratio of Confederate Commodity/Currency Prices 1861-1865

(January 1861=1)

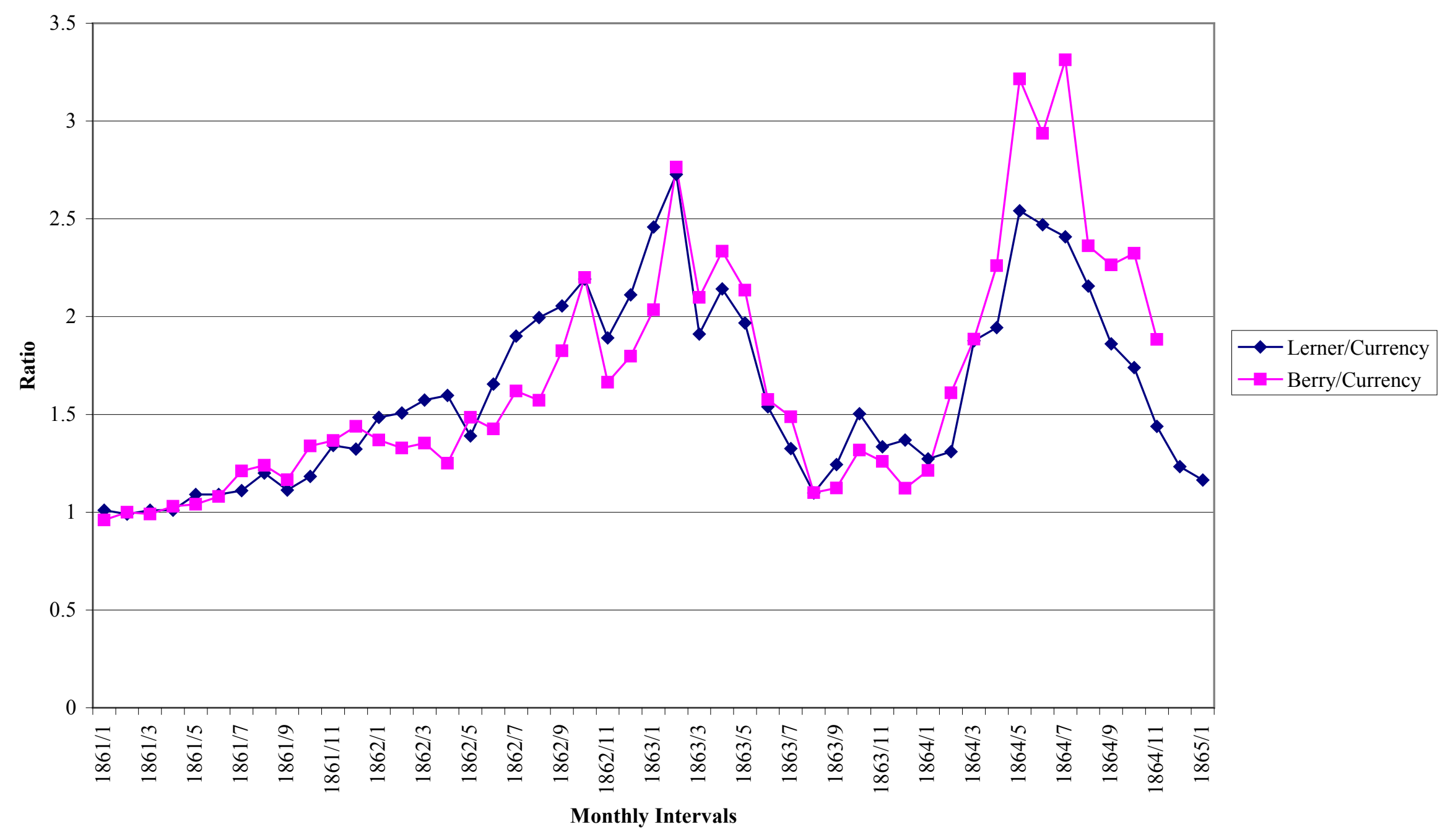


Figure 3

Gold Yields on the Confederate 100 Million Dollar Loan

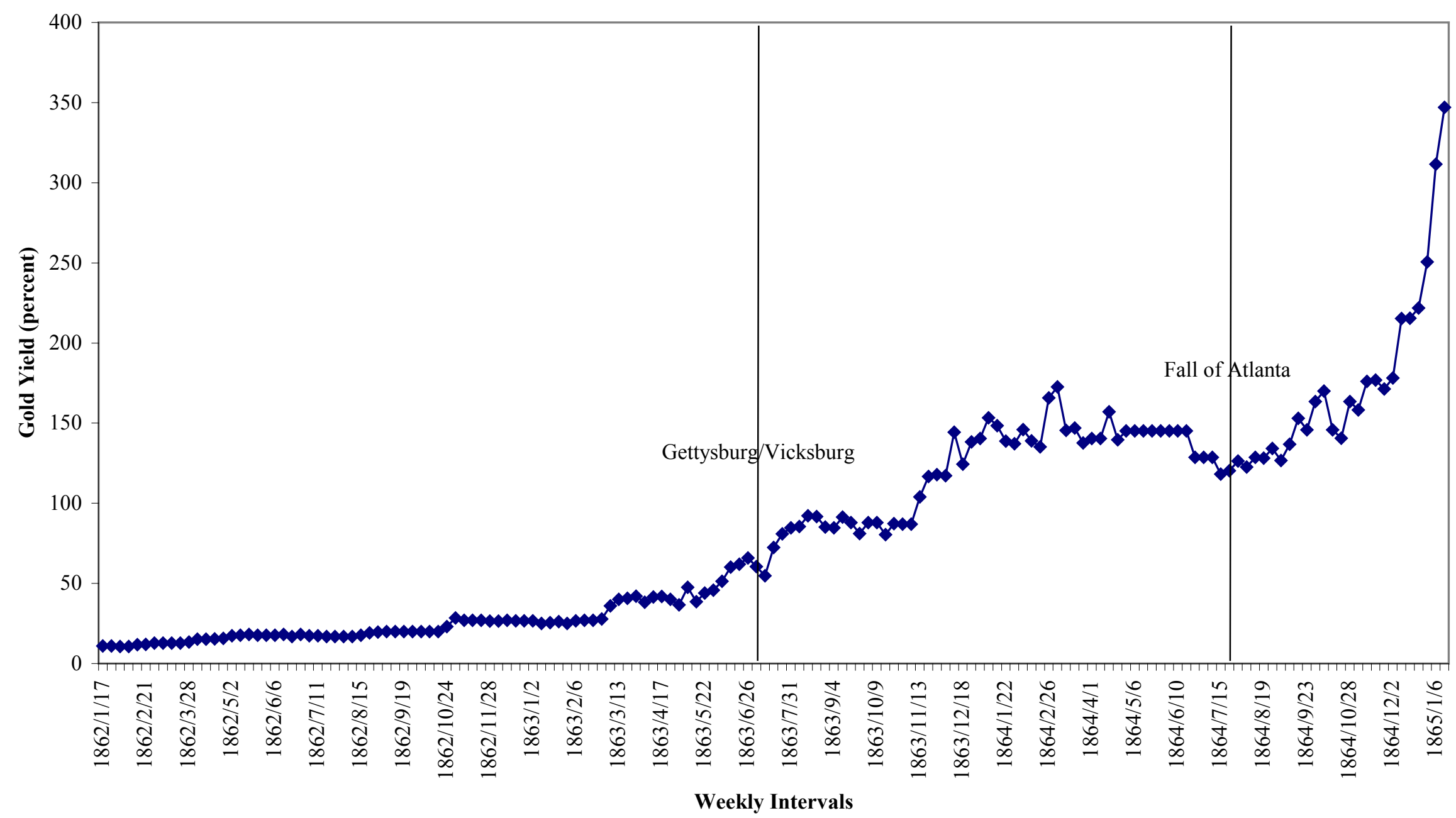


Figure 4

Confederate Money and Bond Prices January 1862 - February 1865

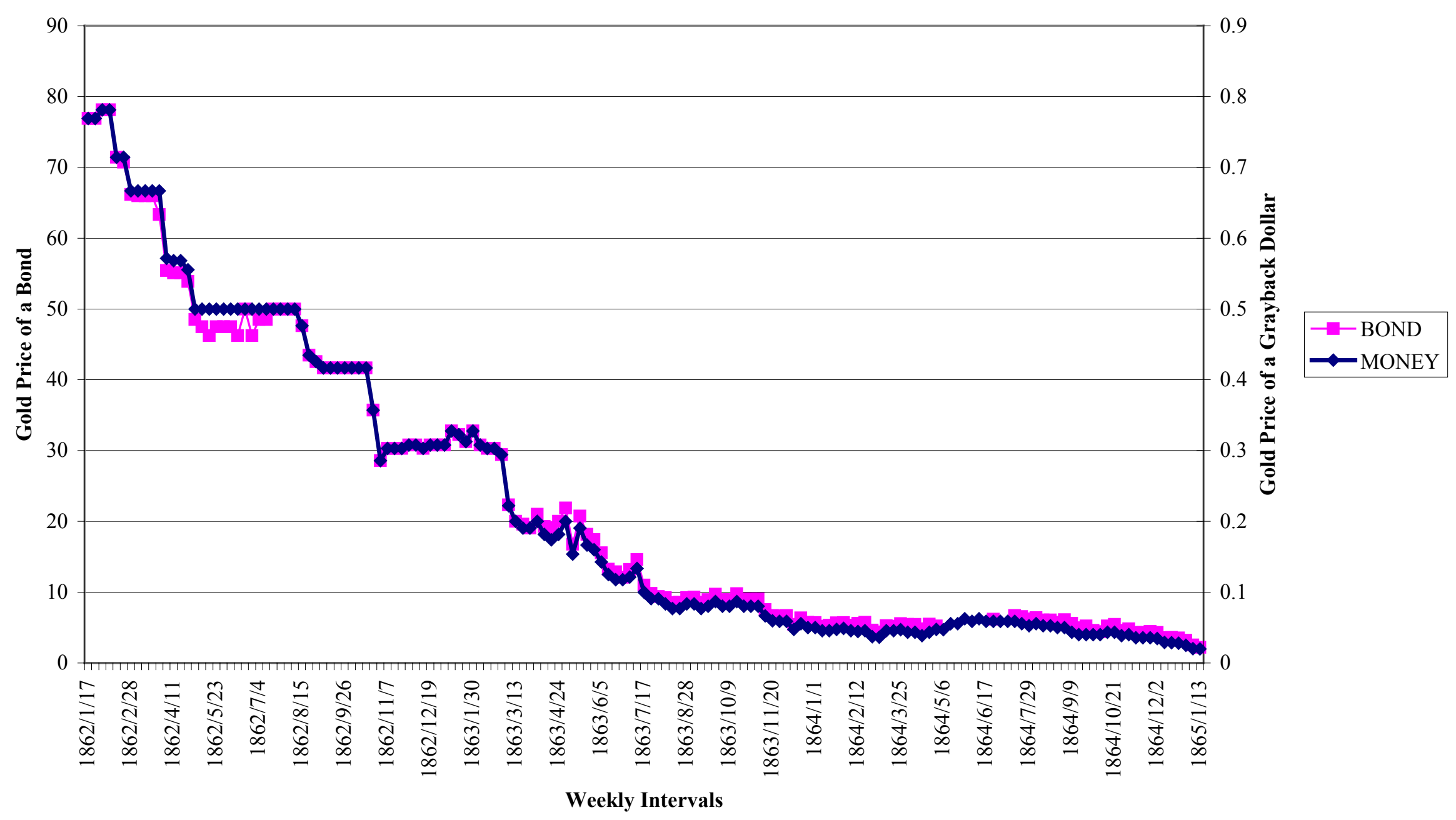




\section{Data Appendix: Confederate Bond Prices of the 100 Million Dollar Loan}

\begin{tabular}{|c|c|c|c|c|c|}
\hline January 17 & 100 & July 18 & 100 & January 9 & 100 \\
\hline January 24 & 100 & July 25 & 100 & January 16 & 100 \\
\hline January 31 & 100 & August 1 & 100 & January 23 & 100 \\
\hline February 7 & 100 & August 8 & 100 & January 30 & 100 \\
\hline February 14 & 100 & August 15 & 100 & February 6 & 100 \\
\hline February 21 & 99 & August 22 & 100 & February 13 & 100 \\
\hline February 28 & 99.25 & August 29 & 100 & February 20 & 100 \\
\hline March 7 & 99 & September 5 & 100 & February 27 & 100 \\
\hline March 14 & 99 & September 12 & 100 & March 6 & 100.5 \\
\hline March 21 & 99 & September 19 & 100 & March 13 & 100 \\
\hline March 28 & 95 & September 26 & 100 & March 20 & 103 \\
\hline April 4 & 97 & October 3 & 100 & March 27 & 100 \\
\hline April 11 & 97 & October 10 & 100 & April 3 & 105 \\
\hline April 18 & 97 & October 17 & 100 & April 10 & 106 \\
\hline April 25 & 97 & October 24 & 100 & April 17 & 110 \\
\hline May 2 & 97 & October 31 & 100 & April 24 & 110 \\
\hline May 9 & 95 & November 7 & 100 & May 1 & 109.5 \\
\hline May 16 & 92.5 & November 14 & 100 & May 8 & 109 \\
\hline May 23 & 95 & November 21 & 100 & May 15 & 109 \\
\hline May 30 & 95 & November 28 & 100 & May 22 & 109 \\
\hline June 6 & 95 & December 5 & 100 & May 29 & 109 \\
\hline June 13 & 92.5 & December 12 & 100 & June 5 & 109 \\
\hline June 20 & 100 & December 19 & 100 & June 12 & 106 \\
\hline June 27 & 92.5 & December 26 & 100 & June 19 & 109.5 \\
\hline July 4 & 97 & 1863 & & June 26 & 103 \\
\hline July 11 & 97 & January 2 & 100 & July 3 & 109 \\
\hline
\end{tabular}




\begin{tabular}{|c|c|c|c|c|c|}
\hline July 10 & 109.5 & January 15 & 117 & September 30 & 115 \\
\hline July 17 & 110 & January 22 & 119 & October 7 & 110 \\
\hline July 24 & 108 & January 29 & 117 & October 14 & 120 \\
\hline July 31 & 103 & February 5 & 117 & October 21 & 125 \\
\hline August 7 & 111 & February 12 & 125.5 & October 28 & 120 \\
\hline August 14 & 111 & February 19 & 126 & November 4 & 120 \\
\hline August 21 & 111.5 & February 26 & 125.5 & November 11 & 120 \\
\hline August 28 & 111 & March 4 & 120 & November 18 & 120 \\
\hline September 4 & 111.5 & March 11 & 115.5 & November 25 & 125 \\
\hline September 11 & 111.5 & March 18 & 114 & December 2 & 125 \\
\hline September 18 & 111.5 & March 25 & 118 & December 9 & 122.5 \\
\hline September 25 & 111.5 & April 1 & 125 & December 16 & 125 \\
\hline October 2 & 111.5 & April 8 & 125 & December 23 & 127.5 \\
\hline October 9 & 111.5 & April 15 & 125 & December 30 & 127.5 \\
\hline October 16 & 112.5 & April 22 & 125 & 1865 & \\
\hline October 23 & 112.5 & April 29 & 110 & January 6 & 125 \\
\hline October 30 & 113 & Reform Act & & January 13 & 110 \\
\hline November 6 & 113 & July 15 & 114 & & \\
\hline November 13 & 113 & July 22 & 118 & & \\
\hline November 20 & 112 & July 29 & 118 & & \\
\hline November 27 & 113 & August 5 & 115 & & \\
\hline December 4 & 114 & August 12 & 115 & & \\
\hline December 11 & 114 & August 19 & 115 & & \\
\hline December 18 & 114.5 & August 26 & 115 & & \\
\hline December 25 & 115 & September 2 & 122 & & \\
\hline 1864 & & September 9 & 129 & & \\
\hline January 1 & 114 & September 16 & 124 & & \\
\hline January 8 & 114 & September 23 & 130.5 & & \\
\hline
\end{tabular}




\section{Confederate Price Indices}

\begin{tabular}{|c|c|c|c|c|c|}
\hline & Lerner Price Index & Berry Price Index & Currency Index & Lerner/Currency & Berry/Currency \\
\hline $1861 / 1$ & 101.00 & 96.00 & 100.00 & 1.01 & 0.96 \\
\hline $1861 / 2$ & 99.00 & 100.00 & 100.00 & 0.99 & 1.00 \\
\hline $1861 / 3$ & 101.00 & 99.00 & 100.00 & 1.01 & 0.99 \\
\hline $1861 / 4$ & 101.00 & 103.00 & 100.00 & 1.01 & 1.03 \\
\hline $1861 / 5$ & 109.00 & 104.00 & 100.00 & 1.09 & 1.04 \\
\hline $1861 / 6$ & 109.00 & 108.00 & 100.00 & 1.09 & 1.08 \\
\hline $1861 / 7$ & 111.00 & 121.00 & 100.00 & 1.11 & 1.21 \\
\hline $1861 / 8$ & 120.00 & 124.00 & 100.00 & 1.20 & 1.24 \\
\hline $1861 / 9$ & 128.00 & 134.00 & 115.00 & 1.11 & 1.17 \\
\hline $1861 / 10$ & 136.00 & 154.00 & 115.00 & 1.18 & 1.34 \\
\hline $1861 / 11$ & 161.00 & 164.00 & 120.00 & 1.34 & 1.37 \\
\hline $1861 / 12$ & 172.00 & 187.00 & 130.00 & 1.32 & 1.44 \\
\hline $1862 / 1$ & 193.00 & 178.00 & 130.00 & 1.48 & 1.37 \\
\hline $1862 / 2$ & 211.00 & 186.00 & 140.00 & 1.51 & 1.33 \\
\hline $1862 / 3$ & 236.00 & 203.00 & 150.00 & 1.57 & 1.35 \\
\hline $1862 / 4$ & 281.00 & 220.00 & 176.00 & 1.60 & 1.25 \\
\hline $1862 / 5$ & 278.00 & 297.00 & 200.00 & 1.39 & 1.49 \\
\hline $1862 / 6$ & 331.00 & 285.00 & 200.00 & 1.66 & 1.43 \\
\hline $1862 / 7$ & 380.00 & 324.00 & 200.00 & 1.90 & 1.62 \\
\hline $1862 / 8$ & 419.00 & 330.00 & 210.00 & 2.00 & 1.57 \\
\hline $1862 / 9$ & 493.00 & 438.00 & 240.00 & 2.05 & 1.83 \\
\hline $1862 / 10$ & 526.00 & 528.00 & 240.00 & 2.19 & 2.20 \\
\hline $1862 / 11$ & 624.00 & 549.00 & 330.00 & 1.89 & 1.66 \\
\hline $1862 / 12$ & 686.00 & 584.00 & 325.00 & 2.11 & 1.80 \\
\hline $1863 / 1$ & 762.00 & 631.00 & 310.00 & 2.46 & 2.04 \\
\hline $1863 / 2$ & 900.00 & 912.00 & 330.00 & 2.73 & 2.76 \\
\hline $1863 / 3$ & 1051.00 & 1154.00 & 550.00 & 1.91 & 2.10 \\
\hline $1863 / 4$ & 1178.00 & 1284.00 & 550.00 & 2.14 & 2.33 \\
\hline $1863 / 5$ & 1279.00 & 1388.00 & 650.00 & 1.97 & 2.14 \\
\hline $1863 / 6$ & 1308.00 & 1340.00 & 850.00 & 1.54 & 1.58 \\
\hline $1863 / 7$ & 1326.00 & 1488.00 & 1000.00 & 1.33 & 1.49 \\
\hline $1863 / 8$ & 1428.00 & 1429.00 & 1300.00 & 1.10 & 1.10 \\
\hline $1863 / 9$ & 1617.00 & 1461.00 & 1300.00 & 1.24 & 1.12 \\
\hline $1863 / 10$ & 1879.00 & 1646.00 & 1250.00 & 1.50 & 1.32 \\
\hline $1863 / 11$ & 2236.00 & 2110.00 & 1675.00 & 1.33 & 1.26 \\
\hline $1863 / 12$ & 2464.00 & 2020.00 & 1800.00 & 1.37 & 1.12 \\
\hline $1864 / 1$ & 2801.00 & 2670.00 & 2200.00 & 1.27 & 1.21 \\
\hline $1864 / 2$ & 2947.00 & 3624.00 & 2250.00 & 1.31 & 1.61 \\
\hline $1864 / 3$ & 4128.00 & 4146.00 & 2200.00 & 1.88 & 1.88 \\
\hline $1864 / 4$ & 4470.00 & 5200.00 & 2300.00 & 1.94 & 2.26 \\
\hline $1864 / 5$ & 4575.00 & 5788.00 & 1800.00 & 2.54 & 3.22 \\
\hline $1864 / 6$ & 4198.00 & 4993.00 & 1700.00 & 2.47 & 2.94 \\
\hline $1864 / 7$ & 4094.00 & 5632.00 & 1700.00 & 2.41 & 3.31 \\
\hline $1864 / 8$ & 4097.00 & 4488.00 & 1900.00 & 2.16 & 2.36 \\
\hline $1864 / 9$ & 4279.00 & 5208.00 & 2300.00 & 1.86 & 2.26 \\
\hline $1864 / 10$ & 4001.00 & 5344.00 & 2300.00 & 1.74 & 2.32 \\
\hline $1864 / 11$ & 4029.00 & 5274.00 & 2800.00 & 1.44 & 1.88 \\
\hline $1864 / 12$ & 4285.00 & & 3475.00 & 1.23 & 0.00 \\
\hline $1865 / 1$ & 5824.00 & & 5000.00 & 1.16 & 0.00 \\
\hline
\end{tabular}


